\title{
The Pure Land Revisited: Sino-Japanese Meditations and Near-Death Experiences of the Next World
}

\author{
Carl B. Becker \\ Osaka University Faculty of Letters \\ Osaka, Japan
}

\begin{abstract}
This article reviews the objects and techniques of Buddhist meditation used to obtain visions of the Pure Land (or "next world"), and considers the Buddhist response to criticisms of such meditative visions of the Pure Land; examines the theory and philosophy of deathbed visions as presented within Buddhism, adducing Japanese deathbed visions from the historical literature; and places these visions within the context of the Buddhist world-view to show how the Buddhists made consistent sense of their experiences. It is found that deathbed imagery is indigenous and integral to Pure Land Buddhism; that ancient Japanese Buddhist meditative and deathbed visions closely parallel modern American near-death and deathbed visions; and that the Buddhist philosophy of idealism provides a coherent model of a "next world" capable of integrating and interpreting these experiences.
\end{abstract}

\section{INTRODUCTION}

In a previous article (Becker, 1981), I discussed the theories of Pure Land Buddhism and its introduction to China, and documented the importance of near-death experiences (NDEs) to its origins and theology using numerous examples. I shall not here repeat the background nor history detailed in that article; rather, the present article is a deeper analysis of Pure Land Buddhist practices, and an extension of that research into the Japanese context. This research demonstrates that Pure Land Buddhists believed that visions of heaven that they experienced while in rigorous meditation were essentially identical in form and content to those of the deathbed; that in fact, monks could deliberately obtain a near-death experience while in trance and thus gain repeated glimpses of the world to come before they finally entered it at death. I shall note some of the better-known cases of the many monks to have done so, and I shall also note numerous histories, both in China and Japan, of non-

\footnotetext{
Anabiosis - The Journal for Near-Death

Studies, Spring 1984, Vol. 4, No. 1
} 
meditating laymen who had similar visions on their deathbeds.

These observations need not contradict my previous study. In my previous article, I pointed out that the origins of each transmission of the Pure Land faith to China were traceable to people who had near-death experiences while largely unaware of the Pure Land tradition, and who embraced Pure Land Buddhism because it made such good explanatory sense of their life-changing experiences. This article, however, is to show rather that once the religion was established, it set up regular procedures for observing deathbeds and/or seeing into the next world, and even conducted critical debates as to the nature and reality of such religious near-death experiences.

Like the earliest Buddhists, Sino-Japanese Mahayana Buddhists considered themselves to be basing their philosophy on real experience, not fantasy. In that sense, they may be called empiricistsalthough without the mechanistic materialist presuppositions that traditionally have dominated Western empiricism. Pure Land Buddhists accepted the provisional reality of all experiences, including dreams, visions, and meditative states (Becker, 1981, pp. 157-159). In particular, their meditative experiences tended to shed doubt on the ultimacy of this realm of sense-impressions and its underlying "objective reality." The verification of the existence and the investigation of the nature of the Pure Land was considered to be within the capacities of all sincere Pure Land Buddhist practitioners. Meditative vision-a long-standing Buddhist practice for gaining true knowledgeis the first "tool" of Pure Land epistemology, and its origins stem from the scriptures themselves.

\section{MEDITATION}

\section{Objects of Meditation}

The Meditation on Amitayus Sutra is a veritable handbook of the procedures to be followed in order to gain a vision of the Bodhisattva Amida, famed for his role in coming to greet the dying at their deathbeds (Takakusu, 1894). The sutra begins by describing meditation on physical objects, such as the setting sun or a bowl of water. The meditator is told to fix the objects permanently in his mind, so that he can visualize them realistically even with his eyes closed. This process, which we have called meditation, is not a discursive thinking "about" these things, but an envisioning, an imaging so clear that the object of concentration actually seems to stand objective 
in its own right in front of the visualizer. Then the practitioner is told to hold the apparently externalized thought-image steadfast, and to inspect the image in minute visual detail (cf. Pas, 1974, pp. 100-103).

Following the meditations on the sun, water, and physical objects, the Meditation Sutra tells the practitioner to visualize jewel trees, flowers, and then buildings of the Pure Land. Thereafter, he is to focus on the Buddha Amitayus and his surrounding bodhisattvas in minute and attentive detail. As he focuses on each tiny part of the image, or mark of the Buddha, it seems to expand and loom immense before him. Finally, he is told to meditate upon (realistically visualize) his own rebirth in the Pure Land:

Imagine thyself to be born in the world of highest happiness in the western quarter, and to be seated cross-legged, on a lotus flower there. Then ... thine eyes will be opened so as to see the Buddhas and bodhisattvas who fill the whole sky; thou wilt hear the sounds of waters and trees, the notes of birds and the voices of many Buddhas preaching the excellent Law in accordance with the twelve divisions of the scriptures. When thou hast ceased from that meditation, thou must surely remember the experience ever after. . . . The innumerable incarnate bodies of Amitayus, together with those of Avalokitesvara and Mahasthamaprapta, constantly come and appear before such devotees [who have achieved this state] (Takakusu, 1894, p. 186).

Although the Meditation Sutra does not detail the postures and preparations for meditation, much of that may be assumed to have been known already by practicing Buddhists, and therefore superfluous.

\section{Practice of Pure Land Meditation}

One early development in Chinese Pure Land meditation and practice was the establishment of the White Lotus Group on Mount Lu-Shan by Hui-yuan in 402 A.D. (Zurcher, 1959, pp. 219-220). Hui-yuan himself was both interested in and personally prone to having visions of the Pure Land. He encouraged both meditation and the painting of imagery conducive to visualization by his followers. $\mathrm{He}$ was frequently ill in his later years, but his writings about the subtle powers of the soul, "moving detached from individual/physical bodies," are very similar to descriptions of modern out-of-body experiences (Ch'en, 1964, p. 111). Visions were widely reported among his disciples as well. Liu Ch'eng-chih, who had helped to draft the charter of the White Lotus Society, saw images of the Buddha 
floating in the air around him after his meditations (as we saw the Meditation Sutra had predicted). He also predicted the date of his own funeral and passed away sitting upright and facing west, without a trace of disease, a description that may indicate that he saw the Pure Land at his death as well (Zurcher, 1959, p. 221).

Shan-tao too had many impressive visualization experiences that inspired his art, his teaching, and his life (Pas, 1974, pp. 113-115; 1976 , p. 10). He encountered the Pure Land in repeated trance experiences, which he attempted to communicate through sermon and sculpture; he was so convincing that at least one listener promptly committed suicide in the hopes of attaining the Pure Land (Chappell, in press). Among Chinese meditators, Shan-tao is the most clear in discussing the practical aspects of Pure Land meditation. To obtain such visions of the Pure Land, he said, one should ritually purify himself, limit his diet to small amounts of rice and vegetables, control his mind, repeat tens of thousands of mantras, and go without sleep for seven days! (Pas, 1976, pp. 22, 25)

In another context, he declared that confessions of one's sins should leave the practitioner crying streams of tears-an emotional catharsis-preparatory to these meditations (Pas, 1974, p. 105).

Master Fa-chao was often called "the second Shan-tao." He had a vision of his master-to-be (Cheng-yuan) while in meditation on the Pure Land and promptly sought him out (Fujiwara, 1974, pp. 134$136,146)$. Fa-chao had numerous visions in his practice of constantly walking meditation and felt that he had been taught a new fivetone mantra recitation by Amida himself while in meditation (Chihpan, 1966, pp. 69-73). It was this same Fa-chao who became the teacher of Ennin (Jap.: Jikaku), who was visiting from Japan and who in turn conveyed the practices and teachings to Mt. Hiei, the center of Japanese Tendai Buddhism.

Among the Tendai masters most famous in Japan today for their emphasis on Pure Land meditation is Genshin (945-1017). Genshin described their constantly walking meditation practice on Mt. Hiei in the following terms:

For a single period of 90 days only circumambulate exclusively. . . You should make this vow: "Even if my bones should wither and rot, I will not rest until I realize this samadhi." If you arouse the great faith, nothing can equal you; no one can rival the wisdom which you will enter into. Thus always obey your teacher. Until three months have passed, have no worldly desires even for the snap of a finger. Until three months have elapsed, do not lie down even for the snap of a finger. Until the three months have elapsed, constantly walk without stopping [except for natural functions] ... (Andrews, 1974, p. 78). 
Genshin is perhaps best known for his Essentials of Rebirth ( $\bar{O} j \bar{o} y \bar{o} \operatorname{sh} \bar{u})$ and his paintings of hells and of the Pure Land, which gave a substantial impetus to Amida-worship in Japan. The important thing to note about Genshin's paintings in this context is that they were inspired by his vivid dreams and visions (de Visser, 1935, pp. 327, 334). Rensei related: "It was after his dreams that Genshin wrote the $\bar{O} j \overline{o y} \bar{o} h \bar{u}$, and Chingai his Ketsujo Ōjōsh $\bar{u}$ [another work of Pure Land visions]" (Ishizuka, 1925, p. 493). Rensei himself predicted the hour of his own death based on his visions, and his passing was accompanied by heavenly music (Ishizuka, 1925, p. 499).

Also on Mt. Hiei, the Bishop Ryonin, who had meditated for years at the Mudo-ji (temple), changed his lifestyle and left the mountain to start the first Japanese Amidist sect, based on a vision:

In 1117 , at the age of 46 , Ryonin experienced the most significant event in his life... . Amida appeared during his nembutsu meditation and directly revealed the philosophy of the yuzu nembutsu as the pathway to salvation. At the same time, [Ryonin] was presented with a visual mandala of Amida (Matsunaga, 1976, pp 13-14).

Ryonin thereupon went directly to the capital, converted the emperor, and had several visions of Bishamonten, one of which left him a scroll "as proof of the heavenly visit" (Matsunaga, 1976, p. 14). The scroll of course no longer exists, but the philosophically interesting point is that no one protested the impossibility of the interaction of the visionary world with the physical world in such a way, since both are seen as being in some sense illusory and equally ideational.

Gods also appeared to Ryonin's disciple Eiku while he was praying (Ishizuka, 1925, p. 203), and it was this same Eiku (along with Koen, compiler of the Fuso Ryakki, of which more below) who was to train the monk Genku, better known as Honen, the Buddhist saint. Honen emulated Shan-tao particularly because "Master Shantao embodied the virtues of samadhi [meditative vision]" (Bando, 1974, pp. 41-42). Honen also believed strongly in meditation. In the first two months of 1198 (A.D.) alone, he perfected the meditations on water, on the lapis lazuli land, on the jeweled lakes and towers, and on the lapis lazuli palace of the Pure Land, as described in the scriptures (Honen Shonin den Zenshu, 1967, pp. 863-864). So numerous and important were Honen's visions that he kept a careful record of them for eight years (1198-1206), with the notation that they were to be kept private until his death (Fujikoshi, 1971, pp. 121-127). 
It is interesting that Honen's greatest opponent and detractor, Koben (Myoe) respected Honen for his meditations throughout his life. It was only after the posthumous publication of Honen's Senchakushu, which advocates recitation over meditation, that Koben attacked his position (Tanabe, 1983). Koben himself kept an elaborate record of his dreams for 40 years, "seemingly indicative of an inherent inclination to fall easily into samadhi, and also of his serious reverence for such experiences" (Tanabe, 1983). Koben was of the Kegon school and Honen of the Tendai. But Koben's protest was not against Honen's use of Pure Land imagery; on the contrary, it was that Honen's advocacy of recitation over meditation (posthumously uncovered) strayed from true Pure Land practice! (Bando, 1974, p. 40). Thus, even monks from non-Pure Land schools respected Pure Land meditation as a central practice and a key to verification of their scriptures.

\section{Critiques of Pure Land Meditation}

Modern medical studies have shown that practices of sensory deprivation, sleeplessness, or emotional catharsis alone are enough to produce visions. In Pure Land Buddhism, such practices were taken together with incessant mantra repetitions, and the conscious desire to project images of heavens or the Buddha of the next world. There can be little doubt, therefore, that some such visions were experienced as reported by some practitioners. The experiences themselves are hardly surprising, given the conditions undergone to generate them.

The critical point at issue, however, is that modern medics will tend to interpret such experiences as non-referential hallucinations of an unbalanced and disease-prone mind. That is based on their presupposition that the material world as perceived is the only normal and "real" standpoint. Pure Land Buddhists, however, would say that it is precisely such meditative experiences that give the lie to the modern materialists' assumptions; that visions demonstrate that there are in fact other layers or levels to reality, which is itself ultimately mind-dependent.

That the debate between such philosophical idealism and materialism is essentially unresolvable has been well illustrated in the debates between Hegel and Marx in the West. Such debates have been useful in illustrating that philosophical idealists can deal with the evidence of the physical senses just as adequately as can any materialist. In fact, outside of Buddhism, there are Vedantins and Christian 
Scientists (among others) who are committed to the ultimate unreality of matter and the supe colng reality of Mind. The strangeness of Pure Land Buddhist idealisin anne is no count against its potential validity as a framework for $i$ itripeting experience.

However, there is yet at point to be considered: even Pure Land Buddhists who lacked meditative experiences were able to experience similar visions $\mathrm{C} n$ their deathbeds or in NDEs. Since the content of the NDEs and the content of the monks' meditative visions were strikingly similar, the Buddhists accepted them both as glimpses of the same nether world, providing further substantiation for their faith. Let us look deeper, then, into the theory and nature of the near-death visions of the Buddha Amida coming to meet the dying person.

\section{The Buddhist Theory of Deathbed Visions}

Even in early Buddhism, the focus of consciousness at the moment of death was thought to have particular importance for the nature of rebirth (Tanabe, 1983, pp. 317-318). While the Hindus envisioned karma as some supernatural storehouse of seeds waiting to bear fruit, and the Jains depicted karma as subtly material dust clinging to the soul, the Buddhists thought only of moments, each influencing subsequent moments in and through themselves. While it seems probable that bad men would harbor bad thoughts, and good men, good thoughts at their deaths, that need not necessarily be the case. The Buddha reported that in his enlightenment experience, he had seen bad men born into good situations, and vice versa, depending in part on the nature of their thoughts at the moments of their deaths (Fujita, 1970, p. 575). When King Milinda (Menander) asked how an evil man with sins as weighty as a stone could fail to fall in to hell at death, it was explained that even a stone could float if placed in a boat (Trenckner, 1962, pp. 17-27). In Pure Land Buddhism, the divine grace of Amida is analogized to this boat, which can save all men regardless of their misdeeds, if they simply trust in it. There are also Hindu precedents for the idea, which was developed more thoroughly by later Vedantins (Fujita, 1970, p. 577).

All three of the Pure Land sutras are predicated on the view that man's consciousness at death can enable his rebirth into the Pure Land, through the miraculous power and aid of Amida. The Larger Sutra makes this explicit in the 19th (Sanskrit, 18th) vow:

O Bhagavat, if those beings who have directed their thoughts towards the 
highest perfect knowledge in other worlds, and who, after having heard my name, when I have approached the Bodhi [enlightenment] have meditated on me with serene thoughts; if at the moments of their deaths, after having approached them surrounded by an assembly of Bhiksus, I should not stand before them, worshipped by them, so their thoughts may not be troubled, may I not obtain the highest perfect knowledge [which is already obtained] (Muller, 1894, p. 15).

We find a text of similar import in the Smaller Sutra as well:

Whatever son or daughter of a family shall hear the name of the blessed Amitayus, the Tathagata, and having heard it, shall keep it in mind ... when that son or daughter of a family comes to die, then that Amitayus, the Tathagata, surrounded by an assembly of disciples and followed by a host of Bodhisattvas, will stand before them at the hour of death, and they will depart this life with tranquil minds. After their deaths, they will be born in the world Sukhavati [The Pure Land], in the Buddha country of the same Amitayus .... (Muller, 1894, p. 99).

The Meditation Sutra goes into still more elaborate detail, describing how the deathbed experiences of people will differ according to the nature of their meditations and faith. Thus, the most accomplished of meditators sees Amida surrounded by countless Bodhisattvas, his land and palace, all at once, and Amitayus sends radiant light to shine upon the face of the dying believer. Those of lesser belief see flowers, thrones, and different colors of light according to their grades. The lowest grades of people to be born into the Pure Land first briefly taste the fires of hell, and then are rescued into flower-covered lakes, or they may see a sun-like disc (but not Amida) to be followed by birth in to the Pure Land 49 days thereafter (from Takakusu, 1894, pp. 189-198). The important thing about these scriptural descriptions is that they tally with experiential accounts that have been preserved.

\section{Records of Deathbed Visions in Pure Land Buddhism}

We have seen that meditating monks validated their religious faith by their ascetic visualization practices, and later found that the images of Buddha spontaneously appeared before them. But even those Pure Land Buddhists who were not meditating monks were taught to expect Amida to meet them at their deathbeds, if they were at peace with the cosmos (Rhys-Davids, 1941, p. 657). Some recent commentators have tried to reinterpret Pure Land Buddhism in a more existential and less soteriological sense, but that simply 
does not square with the clear meaning of the three central Pure Land scriptures. The interpretation is particularly unequivocal in the Chinese of T'an-luan (1974, p. 83).

There were occasional pre-Buddhist accounts of Chinese people who "visited heaven" on their deathbeds, or who died and were subsequently resuscitated, after which they described their experiences to astounded witnesses (de Groot, 1972, p. 7). There were pre-Pure Land Buddhist accounts of visions of heaven at the death of Master Tao-an (a devotee of Maitreya) and of others (de Visser, 1935, p. 328). But the first Pure Land master widely recognized by Japanese Pure Land scholars was T'an-luan. T'an-luan "saw a golden gate open before him" while recovering from a grave illness. That inspired him to seek more knowledge about the afterlife. He studied first Taoist and then Buddhist texts, finally accepting the Pure Land sutras given him by Bodhiruci as the truth (Ch'en, 1964, p. 344). His spiritual disciple, Tao-ch'o, also had a grave illness at age 65. $\mathrm{He}$ felt himself to be dying, when suddenly he had a vision of T'anluan, who commanded him to continue teaching (Lai, in press). It is recorded that T'an-luan's voice was heard by all present, whereupon Tao-ch'o quickly recovered, gained a new set of teeth, and was revered like a god by his disciples as he continued to preach for 18 more years (Chappell, in press).

Tao-ch'o's disciple, Shan-tao, has already been discussed as an advocate of meditations on the Pure Land. Shan-tao placed no lesser importance on the visions at the moment of death, and invoked his monks who tended the deathbeds of Pure Land Buddhists as follows:

If the [dying] patient has a vision, let him tell the attendant about it. As soon as you have heard it, record it just as you have heard. Moreover, when the sick person is not able to relate it, the attendant should ask... "What kind of vision do you see?" If he tells of seeing his sinful deeds [= a life review?], let those beside him reflect on the Buddha for him, and assist him in his repentances and thoroughly cancel the sinful deeds. If the sinful deeds are canceled, and he sees before him in response to his Buddha-reflection the lotus dais holy assembly, record it just as described (Andrews, 1974, p. 83).

The Japanese monk Genshin related the above recommendation with evident approval, showing that it was still in vogue 500 years later. Honen also clearly indicated that it was important to die composed in mind, while reciting the name of Amida continually, to assure the vision of and passage to the Pure Land at death (cf. Ishizuka's 
[1925] chapter "Honen's Teachings to Lay and Clerical Disciples").

It was Chia-ts'ai, who lived shortly after Tao-ch'o, who compiled the first extant collection of deathbed experiences, the Ching-t' $u$-lun (Ogasawara, 1963, pp. 81-89, 107-108). Of the twenty accounts collected, half are of monks, the other half of laypersons. In at least one case, (that of "Dharma-master Chu-Hung") not only the dying person but all present were said to have seen the body of the Buddha coming from the Pure Land to welcome the dying monk (Takakusu, 1920, Vol. 47, 97-98). In other cases, devout laywomen and laymen described visions of heavenly hosts on their deathbeds. In yet another, a butcher first had a vision of hell, whereupon he was terrified into chanting the name of Amida; he then had a vision of Amida offering him the lotus seat, and passed peacefully away (Takakusu, 1920, Vol. 47, p. 99; Ogasawara, 1963, pp. 106-110).

By the 11th century A.D., such accounts numbered more than 100. Lai (in press) typified their deathbed descriptions as follows:

The "visitation" scene is the climax; and this usually involves mysterious fragrance, light, clouds, music, or colors (the best of the senses) and on rare occasions, actual ascent to the West. ... Visions of hells or Pure Lands are common, and no doubt Shan-tao's evangelical zeal in depicting these contrasting destinies in picture helped in inculcating an appreciation of the splendors and horrors of the two alternatives.

In Japan, the first distinctly Buddhist compilation of miracles was the Ryoiki. Its stories date mostly from the years 724-796, and provide specific names, dates (down to the day and hour), and locations for their occurrences, a fact favoring their historicity (cf. Nakamura, 1973, pp. 50, 122). The Ryoiki contains many accounts of human visits to the land of the dead, usually by someone who died and was revived a few days later. The revived persons told of their experiences in bright clouds and golden mountains (Nakamura, 1973, I, p. 5), in golden palaces (Nakamura, 1973, I, p. 30; II, p. 16), or in a hell where sinners were judged by Yama, god of the dead, from which they were sent back and revived (Nakamura, 1973, II, p. 19 ; III, p. 9). In the Nihon Ojo Gokurakuki, not only monks but commoners saw the Pure Land or Maitreya's heaven while temporarily dead (Shigematsu, 1960). In the Konjaku Monogatari of the 11th century, the Bodhisattva Jizo (Sanskrit: Ksitigarbha) saved or escorted the dying people because they led moral lives or worshipped him while they were living. Carmen Blacker summarized:

A remarkable number of tales can be found which describe a priest who 
falls sick and dies. For one reason or another his funeral is delayed and ... he suddenly comes back to life. He has meanwhile been on a long and strange journey, he tells his astonished disciples and friends. . . They cross a dismal river and eventually arrive at a glittering palace ... (Davidson, 1975, p. 45).

Similar tales of deathbed revival with visions of Jizo, Maitreya, or Amida were reported in the Fuso Ryakki, compiled in the mid12th century, covering events through 1094 (Ishizuka, 1925, p. 634). The Fuso Ryakki is important partly for its accounts found in no other sources, and partly because its compiler was the eminent monk Koen of Enryakuji, who taught and ordained Honen (Matsunaga, 1976 , p. 58).

The Uji Shui Monogatari is variously dated from 1188 to 1215 , with the latter date most strongly favored by scholars (Mills, 1970, p. 91). It includes accounts of resuscitated corpses who reported having been saved by Jizo (Mills, 1970, III, pp. 12-13), admonished to lead holier lives (Mills, 1970, VIII, p. 4), or even finding that Jizo and Yama are the same god (Mills, 1970, VI, p. 1). An increasing incidence of tales of hell over those of the Pure Land may reflect the troubled minds of that uncertain era. In Kamakura period Japan, the Genko Shakusho became yet another prominent source of resuscitation records (de Visser, 1914). In one case, the monk Enno died (age 57) and revived, only to find himself deaf and dumb for three years. When he regained his faculties, he spoke of the Pure Land, Maitreya's Palace, Yama's hells, and a miraculous rescue by six figures of Jizo. The catalog of Buddhist rebirth tales continues even up to the present century (Lai, in press). These examples should suffice to show that every age has documented cases of visiting heaven or hell and later returning to the world.

\section{Interpretations of Deathbed Visions of the Pure Land}

We should not assume that the scholars who recorded these deathbed visions were all credulous, uncritical, or propagandizers. Hui-yuan himself was troubled about the ontological status of such visions, and sent many questions to the Indian master Kumarajiva to clarify the proper interpretation of the visions (Zurcher, 1959, p. 227). Sixteenth century Chu-Hung, as another example, was particularly concerned with the status of the "objects" experienced in dying and meditative visionary states. He concluded that although they were mind-dependent, the fact that everyone at death seems to report essentially similar imagery demonstrates that the Pure Land is 
indeed intersubjective and substantial rather than hallucinatory or illusory (Ogasawara, 1963, p. 217). In that conclusion Chu-Hung anticipated Osis and Haraldsson's arguments by four centuries! So Pure Land Buddhists would say that the Pure Land is immediately given through phenomenal experience, and in that sense, empirically verifiable. Phenomenal experience of the Pure Land is confirmed by and found consistent with scriptural, meditative, and deathbed accounts. Moreover, the concept of an immaterial Pure Land fits well into a theory of idealism that makes sense of both this and future worlds in a way that a materialistic metaphysics cannot.

That was the dominant line of Pure Land thought until 1385, when Ryoyo Shogei "wrought nothing short of a revolution" in Pure Land metaphysics by declaring that:

The ordinary conception of the soul's being transported to Paradise and born there was merely a figure of speech. ... . The fact being that neither Amida, nor the sainted beings, nor the "nine ranks" are to be conceived as existing "over there" at all, because the Pure Land is the ultimate and absolute reality, and that is everywhere, so that we may be identified with it right here where we are now (Ishizuka, 1925, p. 57).

That interpretation, which has come to be accepted as the standard by many modern Pure Land Buddhists, was a radical departure from the origins and faith of a millenium of Pure Land practitioners. Despite its deviance from the ontological commitments of the earlier Pure Land Buddhists, even that interpretation is not like the materialistic assertions that there can be no heaven because the known physical world is all that exists. Rather, it asserts that the Pure Land is not a distant place, but a transcendent reality of which we can become conscious here and now through proper practice.

The traditional Pure Land Buddhist could epistemologically justify his knowledge of the Pure Land on several mutually supporting grounds. He could point to the phenomenologically self-validating character of direct experience, and the correspondence between descriptions given in the scriptures and the vision he had while in meditation. To the challenge that daily worldly experiences somehow show his trances to be hallucinatory, he had several replies in favor of his metaphysical idealism, viz.:

1. The idea that the common-sense world is more "real" than the visionary is no more than an unprovable assumption.

2. The idealistic account of visionary experience makes better sense than that of the materialist, for materialists are unable to explain either mental events themselves or the similarities 
of the contents of different persons' visions in physico-chemical terms.

3. The idealistic account makes better sense of survival, which is necessarily of the mind and not of the corpse. If survival of any sort at all is possible, the Buddhist holds that his idealistic world-view is more consistent than either a dualism that must explain the relations between fundamentally different matter and mind, or than an ontological materialism that cannot deal with the survival of disembodied (immaterial) consciousnesses.

\section{CONCLUSIONS}

The issues $I$ have addressed in this article have significant implications for modern scholarship in the areas of religious history, psychology of religion, and philosophy of survival. Let us consider each of these issues in turn.

\section{(1) Amida imagery is not borrowed from other religions.}

Western critics of Pure Land thought have often suggested that Pure Land Buddhism was a Chinese distortion of Indian Christianity (Takakusu, 1947, p. 166), or a borrowing of Zoroastrianism or Manichaeism via the silk routes (Reischauer, 1917, p. 69). The above accounts make clear, however, that it was the meditative experiences of the Chinese themselves that enabled visionaries like T'an-luan to accept the newly imported and otherwise very foreign religious texts of Indian Buddhism. Later Chinese commentaries were based, not on further misunderstandings of Christian sources but on personal religious experiences both of meditation and of witnessing deathbed visions. If parallels are found between Pure Land theology and that of Christianity, they indicate not borrowing but rather the strikingly similar, life-changing religious experience of saints and sages in two very different cultures and philosophies. We need no more say that ancient Buddhist visions were based on primitive Christian scriptures than that modern American visions are based on earlier Buddhist scriptures. In short, the reason that Pure Land Buddhism resembles Christianity is not historical contact but the similarity of religious experience in both cases.

(2) Buddhist descriptions parallel modern medical descriptions.

The descriptions of the Pure Land seen at death and those of 
contemporary statistical and empirical surveys are fascinatingly similar (Ring, 1980; Osis and Haraldsson, 1977). Compassionate figures of golden light, "leading" the dying person to a realm of peace and joy with multicolored flowers, splendid trees, lakes, and pavilions, are reported frequently by modern Western patients as well as by the ancient Chinese and Japanese. The peace and "mood elevation" promised by the sutras is widespread among modern patients with deathbed visions, enabling them to forget or transcend their physically painful conditions. Patients resuscitated from death generally report a realm free from all personal conflict, in which communication is by thought alone. The Buddhists' dark tubular "calyx," which eventually blossoms into the land of light, is a good metaphor for the experiences of many subjects who report being drawn through a dark tube or tunnel. (Of course sensations of the tube, of floating, or of hearing a rush of wind may all be caused by malfunctions of the temporal lobe in drugged or near-death situations, and have no real bearing on the survival question; cf. West, 1962, pp. 78-81; Drab, 1981, pp. 146-147.) Magnification or enlargement of images, and shining geometric patterns or "jeweled nets" are also common to both the later Pure Land sutras and hallucinatory "drug trips" (West, 1962, pp. 156-158). The point of all this is not to reduce it to purely physiological interpretations, which are clearly inadequate to account for the range of phenomena experienced, and which may be correlates but not causes of the experience in any case. Rather, the more interesting point is the relative universality of such experiences in disparate cultures and ages, and their dramatic impact on the lives of those who encountered them. Whether they are archetypes dredged up from some collective unconscious at the moment of death, projections of the subliminal wish-fulfillments common to all men, or genuine glimpses into another realm to follow this one, it is impossible to determine at this point. But we cannot but be struck by the similarities, both of the experiences reported and of the arguments used to interpret them (e.g., by Chu-Hung in China [Ogasawara, 1963] and by Osis and Haraldsson in modern America [1977]). The juxtaposition of our modern data with those of medieval China and Japan, by their extreme coincidence, tends to reinforce the conclusion that such experiences really happened and were not simply some trumped-up hoax or cultural myth alone. Even accounts of deathbed visions and of white or purple clouds in the death chamber need not necessarily be written off as hagiography, if we can believe similar reports by Western witnesses in this century (e.g., Pole, 1917, p. 101). 
(3) Buddhist idealism provides a consistent model of a "next world."

In both the scriptural and experiential accounts of the Pure Land, we have another significant description of what the "next world" might be like, if there is one. This in itself is enough to rule out the objections of certain logical positivists who assert that a coherent conception of what an afterlife might be like cannot even be formulated. These Buddhists describe the Pure Land as a mind-dependent world. It shares certain intersubjective features for all of its "inhabitants," has various regions suited to various types of consciousnesses, and responds in its minor events to the thoughts and wills of its "inhabitants" or experiencer/creators. That is precisely the same sort of world philosopher H. H. Price (1953) has envisioned and defended in making a case for a coherent conception of the afterlife. There is the same notion that bodies will not really exist in the way that they seem to exist in this material world, but that they will feel equally real and present to those who do not yet realize that both body and discrimination are their own mental projections. There is the same notion that there will be several different levels of delusion and projection-all of them feeling equally real to the projectors but intersubjective in more or fewer ways. There is the same notion that there will be no punishment per se, but that gratification of one's physical desires will soon become flat and valueless, while real joy will come in seeking spiritual insights into one's own nature and the nature of Truth.

In fact, since the Pure Land Buddhist formulation is more detailed than Price's, it can help him escape from philosophical difficulties that have often been pointed out in Price's theory. Price's "next world" was criticized because its will-dependent nature leads either to solipsism or destruction of identity, as when several people will to speak to the same person at the same time but in different places. Either each "inhabitant" creates his or her own solipsistic and imaginary world, or if the world is intersubjective, then at least the partner of conversation is split into pieces when many people envision him (project him before themselves) simultaneously. Price has made no clear response to that objection. The Pure Land Buddhists explain that objects are perceptible (because projectible) by the mere thought of them, but human consciousnesses are still uniquely localized in individual discrete places. Thus, one may "conjure" a meal or a bath that one may phenomenally experience by merely thinking of it in the Pure Land. But if one wishes to speak to a person, one must seek that person wherever he or she may be at that 
moment (both spatially and psychologically!), awaiting disengagement from present activity so that he or she may relate to the "conjuror." Thus, in Pure Land Buddhism, the subjectivity of impressions of objects is not incompatible with a higher objectivity of individual consciousnesses and the bodies they project.

In this article, I have surveyed some of the more interesting phenomenological history of Pure Land Buddhism in China and Japan, and discussed the epistemology that is presupposed by Pure Land scriptures and practitioners. We have seen parallels between their meditations and deathbed experiences and observed that idealist philosophy can make good sense of both. We have indicated that Pure Land Buddhism is not borrowed from other religions but is a reflection of common religious experience, pointing to a reality often envisioned in the West as well: a mind-dependent life after death.

\section{REFERENCES}

Andrews, A. The Teachings Essential for Rebirth, A Study of Genshin's Ojōyoshü. Tokyo: Sophia University, 1974.

Bando, S. Myoe's criticisms of Honen's doctrine. Eastern Buddhist (Kyoto, New Series), 1974, 7, 41-49.

Becker, C. B. The centrality of near-death experiences in Chinese Pure Land Buddhism. Anabiosis, 1981, 1, 154-171.

Chappell, D. W. The formation of the Pure Land movement in China:

Tao-ch'o and Shan-tao. In M. Solomon (Ed.), Berkeley Buddhist

Studies, Series 3. Berkeley, CA: Asian Humanities Press (in press). Ch'en, K. K. S. Buddhism in China. Princeton: Princeton University Press, 1964.

Chih-pan. A Chronicle of Buddhism in China, 581-960 A.D. (J. Y. Hua, Trans.). Santiniketan: Visvabharati, 1966.

Davidson, H. R. E. (Ed.). The Journey to the Other Worlds. Cambridge: D. S. Brewer, Ltd., 1975.

de Groot, J. J. M. The Religious System of China. Taipei: Cheng Wen Publishers, 1972.

de Visser, M. W. The Bodhisattva Ti-tsang (Jizō) in China and Japan.

Berlin: Oesterheld \& Co., 1914.

de Visser, M. W. Ancient Buddhism in Japan. Leiden, Holland:

E. J. Brill, 1935.

Drab, K. J. The tunnel experience: reality or hallucination? Anabiosis, $1981,1,126-152$.

Fujikoshi, J. Bannen no Honen Shonin (Saint Honen's last years). Indogaku Bukkyogaku Kenkyu (Joumal of Indian and Buddhist Studies), 1971, 20, 121-127. 
Fujita, K. Genshi Jodo Shiso no Kenkyu (Research on Early Pure Land Thought). Tokyo: Iwanami Shoten, 1970.

Fujiwara, R. The Way to Nirvana. Tokyo: Kyoiku Shinchosha, 1974.

Honen Shonin den Zenshu (The Complete Collection of Biographies of Saint Honen). Osaka: Honen Shonin den Zenshu Kankokai, 1967.

Ishizuka, R. Honen the Buddhist Saint. Kyoto: Chion-in, 1925. Jodoshu Zenshu (The Complete Collection of the Pure Land Religion). Tokyo: Jodoshu Shuten Kankokai, 1910.

Lai, W. Tales of rebirths and the later Pure Land tradition in China. In M. Solomon (Ed.), Berkeley Buddhist Studies, Series 3. Berkeley, CA: Asian Humanities Press (in press).

Matsunaga, D. The Foundation of Japanese Buddhism, II. Tokyo: Buddhist Books International, 1976.

Mills, D. E. A Collection of Tales from Uji (UjiShuiMonogatari). Cambridge: Cambridge University Press, 1970.

Muller, M. (Ed. and Trans.) Sacred Books of the East (Vol. 49). Oxford: Clarendon Press, 1894.

Nakamura, K. Miraculous Stories from the Japanese Buddhist Tradition (the Ryoiki). Cambridge, MA: Harvard University Press, 1973.

Ogasawara, S. Chugoku Kinsei Jodokyoshi no Kenkyu (Research on the History of Pure Land Buddhism in Recent China). Kyoto: Hyakkaen, 1963.

Osis, K., and Haraldsson, E. At the Hour of Death. New York: Avon Books, 1977.

Pas, J. Dimensions in the life and thought of Shan-tao. Paper presented at the Society for the Study of Chinese Religion, American Academy of Religion, St. Louis, MO, October, 1976.

Pas, J. Shan-tao's interpretations of the meditative vision of Amitayus. History of Religions, 1974, 14, 96-116.

Pole, W. T. Private Dowding. London: J. M. Watkins, 1917.

Price, H. H. Survival and the idea of another world. Proceedings of the Society for Psychical Research, 1953, 60, 1-25.

Reischauer, A. K. Studies in Japanese Buddhism. New York: Macmillan, 1917.

Rhys-Davids, C. A. F. A historical aspect of nirvana. In C. A. F. Rhys-Davids (Ed.), Wayfarer's Words (Vol. 2). London: Luzac, 1941.

Ring, K. Life at Death. New York: Coward, McCann and Geoghegan, 1980. 
Shigematsu, A. Ojoden no Kenkyu (Research on tales of rebirth in the Pure Land), Nagoya Daigaku Bungakubu Kenkyu Ronshu (Journal of the Faculty of Literature of Nagoya University), $1960,23$.

Takakusu, J. (Trans.) The Amitāyur-dhyāna-sütra. In M. Muller (Ed.), Sacred Books of the East (Vol. 49). Oxford: Clarendon Press, 1894. Takakusu, J. (Ed.) Taisho Shinshu Daizokyo (Taisho New Great Compendium of Sutras). 100 Vols. Tokyo: Daizo Shuppan, $1920 \mathrm{ff}$. Takakusu, J. Essentials of Buddhist Philosophy. Honolulu: University Press of Hawaii, 1947.

Tanabe, G. Myoe Shonin: tradition and reform in early Kamakura Buddhism. Columbia University Ph.D. thesis. Ann Arbor, MI: University Microfilms, 1983.

T'an-luan. A short essay on the Pure Land (L. Pruden, Trans.). Eastern Buddhist (Kyoto: New Series), 1974, 7, pp. 87 ff.

Trenckner, V. (Ed.). Milindapanha. London: Luzac, 1962.

West, L. J. (Ed.). Hallucinations. New York: Grune \& Stratton, 1962.

Zurcher, E. The Buddhist Conquest of China. Leiden, Holland: Brill, 1959.

Requests for reprints to:

Carl B. Becker

Faculty of Letters

Osaka University

I-I, Machinakeyama-Cho, Toyonaka-shi

Osaka-fu, 560

Japan 